Mahmud, G. F. ' ${ }^{\text {; }}$ El Ghadban, E.A.E ${ }^{2}$ and Shahat, M. S. ${ }^{3}$ and Gamal Ali El Sharnouby ${ }^{3}$

\title{
Physicochemical and phytonutrients Evaluation of Arbequina Extra Virgin Olive oil Cultivated Recently in Egypt
}

\author{
Mahmud, G. F. ${ }^{1}$; El Ghadban, E.A.E ${ }^{2}$ and Shahat , M. S. ${ }^{3}$ and Gamal \\ Ali El Sharnouby ${ }^{3}$ \\ ${ }^{1}$ Functional Foods Department, National Institute of Nutrition Canada, Ottawa \\ ${ }^{2}$ Medicinal and Aromatic Plants Department, Horticultural Research Institute (H.R.I) ARC; \\ National Gene Bank (N.G.B.). \\ ${ }^{3}$ Food Science and Technology Department , faculty of Agriculture, Al Azhar university, Cairo \\ ,Egypt
}

ABSTRACT
His study was conducted in the Department of Medicinal and Aromatic Plants,
Horticulture Research Institute, Agricultural Research Center, Dokki, in
cooperation with the Food Science and Technology Department, Faculty of Agriculture, Al-Azhar University, Cairo, season 2016, Varieties of the olive cultivar Arbequina have recently been cultivated in Egypt. The objective of the study is to characterize and evaluate extra virgin olive oils (EVOO) produced from Arbequina grown in two places in Egypt, is Sheikh Zuid Station, the North Sinai Governorate Center for Desert Research (NS), El Taal al kabeer area, Ismailia (IS), The aim was of the study to evaluate effective nutritive value in the extracted fruits oils, chemical and physical study of those components, $40 \mathrm{~kg}$ of ripe seeds were collected from two places (SN ), (IS), and oil extraction, store at $4^{\circ} \mathrm{C}$ until used.the (NS) and (IS) regions of Egypt. Major and minor components such as carotenoids, squalene, phenolics and tocopherols were studied to assess their effects on product quality and health benefits. Samples were to determine fatty acids composition, sterol composition, TAG profile and squalene content. Individual phenolic fractions were analyzed by LC-MS/MS and tocopherol isomers were determined by HPLC. According to the results obtained from this study; Total phenolic content (TPC) of the samples were 454.68 and $50.86 \mathrm{mg}$ as Gallic acid/kg oil for (NS) and (IS), respectively. Hydroxytyrosol and tyrosol were the main phenols. The major tocopherol isomer found in (NS) and (IS) was $\alpha$-tocopherol with levels of 179.55 and $202.5 \mathrm{mg} / \mathrm{kg}$ oil, respectively. $\beta$-Carotene levels in both samples were similar at $0.2 \mathrm{mg} / \mathrm{kg}$. Findings of this study were compared with the literature on Arbequina olive oil produced in different countries. It was determined that Arbequina olive oil of high quality can be produced in Egypt, especially in the North Sinai Governorate (NS).

Keywords: Extra virgin olive oil (EVOO) - Arbequina variety $\cdot$ Phenolics . Tocopherol $\cdot$ Squalene 
Mahmud, G. F. ${ }^{1}$; El Ghadban, E.A.E ${ }^{2}$ and Shahat, M. S. ${ }^{3}$ and Gamal Ali El Sharnouby ${ }^{3}$

\section{INTRODUCTION}

The olive tree (Olea

Europaea L.) is cultivated largely in Mediterranean countries (Spain, Italy, Greece, Tunisia, Turkey, Morocco and Algeria) for climatic reasons. Traditionally, olive oil has been a major part of the Mediterranean diet. In recent years, its popularity has increased worldwide due to the health benefits derived from its high levels of mono-unsaturated fatty acids, antioxidants and other minor components

(Bakhouche etal. 2013).

The composition of extra-virgin olive oil (EVOO), which is a determining factor in its intrinsic quality, can be influenced by several geographic, agronomic and technological factors

(Bakhouche etal. 2013), such as olive cultivar (Tura etal., 2007) climate, (Lazzez etal., 2008), crop season (Rodney et al., 2014) and the production process (Lozano-Sánchez et al., 2010). Temperature and rainfall may also affect olive oil composition (Romero et al., 2003); (Ilyasoglu et al., 2010). However, specific characteristics of olive oil are largely determined by geographic considerations (Petrakis et al., 2015). Marketing of EVOO is increasingly focused on differentiation and characterization of products from different geographical areas (Bakhouche et al. 2013). Several studies have shown that climatic factors such as those mentioned above have an effect on plant physiology, and consequently on the chemical characteristics of the oil extracted from the plant fruits (Gorinstein etal., 2003); (Pereira etal., 2006); (Ocakoglu etal. 2009).

Arbequina is a Spanish olive cultivar, characterized by small fruits and high oil yield Barranco et al., (1999); Torres and Maestri (2006). This cultivar, which owes its name to the municipal district of Arbeca (Lleida, Catalonia, Spain), where it was first grown, can be characterized by its frost resistance, low vigor, and smallsized fruit (Bakhouche et al. 2013). Although there have been some studies reported by several researchers, including chemical composition of olives. 
Mahmud, G. F. ${ }^{1}$; El Ghadban, E.A.E ${ }^{2}$ and Shahat, M. S. ${ }^{3}$ and Gamal Ali El Sharnouby ${ }^{3}$

In Argentina Carelli, (2008), preliminary characterization of olive oils produced, in Morocco (Mansouri etal., 2013), and chemical characterization of traditional varietal olive oils in Spain (López-Cortés etal., 2013), by there is not a great deal of data on its chemical composition, despite the large amount of Arbequina olive oil produced in Spain and other countries.

The cultivation of the Arbequina variety has recently been initiated in Egypt. Hence, the objective of this work is to characterize chemical composition of EVOO extracted from Arbequina cultivated in two different olive growing areas in Egypt, namely, the North Sinai Governorate (NS), Ismailia (IS). The task of characterizing these oils is important not only to assess their chemical qualities but also to compare them with each other and Arbequina olive oil produced in different countries. The findings of this study may provide ways for quality indication and investigation of environmental effects on olive oils from Arbequina according to their major chemical composition (fatty acid, triglycerides and sterol content), antioxidant content and minor compounds (phenolics, squalene, $\beta$-carotene and $\alpha$-tocopherol content).

To our knowledge, that is the first time that the chemical composition of EVOO produced from the monovarietal Arbequina variety in Egypt has been determined and compared by growing area and with olive oils produced from Arbequina in Spain, Argentina, Tunisia and Morocco with regard to quality characteristics

\section{MATERIALS \& METHODS}

This investigation was carried out at medicinal and aromatic plants Department Horticulture Research Institute Agricultural Research Center Dokki, In cooperation with Food Science and Technology Department, faculty of Agriculture, Al Azhar university, Cairo during the seasons 2016 


\section{Samples}

Source of Arbequina Olive Cultivated in Egypt, seasons 2016,

Samples of Arbequina Olive were obtained taken from two places in Egypt season 2016, as follows:

1. Sheikh Zuid Station, North Sinai Governorate - Center for Desert Research (NS)

2. El Taal al kabeer area, (Ismailia Governorate) Ministry of Agriculture (IS)

\section{Collect mature fruits}

Harvest was done in, October-December. Samples were divided into two groups and identified by their growing province (NS) and (IS), respectively. All of the samples were stored in dark brown bottles at $4{ }^{\circ} \mathrm{C}$ until they could be analyzed.

\section{Get the oil from the fruits}

Oil was extracted using an Abencor laboratory oil mill equipped with a crusher, a mixer and a basket centrifuge. Only healthy fruits, without any kind of infection or physical damage, were processed. After harvesting, fresh olives (40 $\mathrm{kg}$ ) were washed and deleafed, crushed with a hammer crusher, and the paste mixed at $25^{\circ} \mathrm{C}$ for $30 \mathrm{~min}$, centrifuged without the addition of warm water (oil produced from each extraction was $5000 \mathrm{~mL} / \mathrm{kg}$ ) and then transferred into dark glass bottles, and stored at $4^{\circ} \mathrm{C}$ until analysis by (AOCS 2002)

\section{Chemical analysis}

A fatty acid methyl ester (FAME) standard mixture (37 components), a sterol standard mix (6 components) and triacylglycerol (TAG) standard mixture were purchased from Supelco (Bellefonte, PA). All other chemicals and reagents used for analysis were of either analytical or HPLC.

\section{Chemical Parameters}

\section{Quality Index Determination}

Both sets of samples were olive fruits picked at the same stage of ripeness, and their oils were extracted with the same processing system. Determination of free acidity, peroxide value, and specific absorbance at 232 and $270 \mathrm{~nm}$ (K232 and K270) were 
Mahmud, G. F. ${ }^{1}$; El Ghadban, E.A.E ${ }^{2}$ and Shahat, M. S. ${ }^{3}$ and Gamal Ali El Sharnouby ${ }^{3}$

determined according to official methods. The BS EN ISO 660:2009 official method of analysis was used for determination of free acidity values and results were expressed as \% oleic acid. UV absorption characteristics (K232 and K270) were determined by the analytical methods described in the Regulation EC/1989/(2003) using a Jenway $6705 \quad U V$-visible spectrophotometer, with cyclohexane as the blank. AOAC official method 965.33 (2000) was used to determine the peroxide value (PV) and PV was expressed as milliequivalents (meq) of active oxygem per kilogram of oil

\section{Antioxidant Capacity}

\section{ABTS Assay}

The radical scavenging power of the oils was determined by the 2,2'azinobis(3-ethylbenzothiazoline6-sulfonic acid (ABTS) method Re, etal., (1999). ABTS radical cation (ABTS+) stock solution was prepared by reacting 7.0 $\mathrm{mM}$ ABTS stock solution with $2.45 \mathrm{mM}$ final concentration) potassium persulfate in the dark for $16 \mathrm{~h}$. The solution was diluted with ethanol by adjusting the absorbance to $0.700 \pm 0.020$ at $765 \mathrm{~nm} .100 \mu \mathrm{L}$ of the diluted oil samples in ethanol and 2.9 $\mathrm{mL}$ of diluted ABTS+ solution were added. The solution was agitated with a vortex mixer for 20 s. The absorbance was measured after 6 min at $765 \mathrm{~nm}$. The results were expressed as $\mu \mathrm{g}$ Trolox equivalent/100 g oil.

\section{DPPH Assay}

The DPPH $\quad(\alpha, \alpha-$ diphenyl- $\beta$-picrylhydrazyl) assay was also used to determine the radical scavenging power of the oils by method of Bondet et al. , (1997) . Freshly prepared DPPH solution was dissolved in a small volume of ethyl acetate and then diluted with ethyl acetate by adjusting the absorbance to $0.700 \pm 0.020$ at $520 \mathrm{~nm} .20 \mathrm{mg}$ oil was weighed in a test tube, then $80 \mu \mathrm{L}$ ethyl acetate and 2.9 $\mathrm{mL}$ DPPH free radical solution were added. The sample was agitated with a vortex mixer for $20 \mathrm{~s}$. After $30 \mathrm{~min}$ of incubation in darkness at room temperature, absorbance was measured at 520 $\mathrm{nm}$ against ethyl acetate. Trolox was used as a standard and the 
Mahmud, G. F. ${ }^{1}$; El Ghadban, E.A.E ${ }^{2}$ and Shahat, M. S. ${ }^{3}$ and Gamal Ali El Sharnouby ${ }^{3}$

results were expressed as $\mu \mathrm{g}$ Trolox equivalent/100 g oil.

\section{ORAC Assay}

$$
\text { Oxygen Radical }
$$

Absorbance Capacity (ORAC) was determined according to the method Huang etal., (2002) described, $0.5 \mathrm{~g}$ of the oil sample was dissolved in $20 \mathrm{~mL}$ acetone. An aliquot of sample mixture was properly diluted with $7 \%$ randomly methylated $\beta$ cyclodextrin (RMCD) solvent $(\mathrm{w} / \mathrm{v})$ prepared in $50 \%$ acetonewater mixture $(\mathrm{v} / \mathrm{v})$ and then shaken at room temperature for $1 \mathrm{~h}$ on an orbital shaker at 400 rpm. ORAC analysis was carried out by a Biotek Synergy HT spectrophotometer. All reagents were prepared with $75 \mathrm{mM}$ phosphate buffer ( $\mathrm{pH} 7.4$ ), with the exception of samples and Trolox standards, which were prepared in $7 \%$ RCMD solution. In the final assay mixture (0.4 $\mathrm{mL}$ total volume), fluorescence (FL) $\left(6.3 \times 10^{-8} \mathrm{M}\right)$ was used as a target of free radical attack and 2,2'-azobis (2-amidinopropane) dihydrochloride (AAPH) $(1.28 \times$ $\left.10^{-2} \mathrm{M}\right)$ was used as a peroxyl radical generator. Trolox $(6,25$, $12.5,25,50$ and $100 \mu \mathrm{M})$ was used as the control standard and $7 \%$ RMCD was used as a blank. Final results were calculated using the differences of area under the FL decay curves between the blank and a sample. The results were expressed as $\mu$ mol Trolox equivalent/100 g oil.

Color Measurements, Chlorophyll - $a$ and $\beta$-Carotene Determinations

CieLab coordinates $\left(L^{*}\right.$, $a^{*}$, and $b^{*}$ ) were directly read with a spectrophotocolorimeter (Trintometer, Lovibond PFX 195 V 3.2, Amesbury, UK). In this coordinate system, the $L^{*}$ value is a measure of lightness, ranging from 0 (black) to 100 (white), the $a^{*}$ value ranges from -100 greenness) to +100 (redness) and the $b^{*}$ value ranges from +100 (blueness) to -100 (yellowness). Chlorophylla and $\beta$-carotene content of oil samples were also directly read by the Lovibond tintometer (Verleyen et al., 2002).

\section{Fatty Acid Determination}

Fatty acid methyl esters, as converted from the corresponding fatty acids in the 
seed oil according to the method, were analyzed by Philips Pye Unicam PU 4500 (Philips Electronics UK Ltd, Guildford, Surrey, UK) gas chromatography equipped with a flame ionization detector. The column (internal diameter $2 \mathrm{~mm}$, length $1.5 \mathrm{~m}$ ) (Philips Scientific, Cambridge, UK) was filled with $10 \%$ diethyl glycol succinate on a 100 to 200- (British standard sieve) mesh (Mallinckrodt Chemical Works, St. Louis, MO). Injection and detector temperatures were 230 and 250C, respectively. The column temperature was increased from 100 to $225 \mathrm{C}$, with a temperature increase gradient of 4C min-1. Nitrogen gas was used as the carrier gas at a flow rate of 11.3 $\mathrm{mL}$ min-1. The chromatograms were recorded with Spectra Pycis 4290 integrator (Spectra Physics, Irvine, CA). The amount of each fatty acid was given as a percentage of the total fatty acid content.

\section{Sterol Determination}

Sterol content was determined according to a modified procedure of Gutfinger, (1981); Verleyen $e t$ al. (2002). , explained To prepare the unsaponifiable matter, $1.5 \mathrm{~g}$ oil was weighed in a flask and $2 \mathrm{~mL}$ of internal standard $(0.1 \%$ cholesterol in chloro-form) was added. The sample was mixed with $10 \mathrm{M}$ $\mathrm{KOH}$, prepared in $50 \mathrm{~mL}$ methanol, in flasks and shaken at $30{ }^{\circ} \mathrm{C}$ for $24 \mathrm{~h}$. After incubation, $10 \mathrm{~mL}$ distilled water; $1 \mathrm{~mL}$ ethanol and $20 \mathrm{~mL}$ hexane were added. The flask was shaken vigorously in a separating funnel and after separation, the hexane layer was collected. The other layer (including the aqueous/alcohol phase) was extracted twice more with 20 $\mathrm{mL}$ hexane. The combined hexane extracts were dried over anhydrous $\mathrm{Na}_{2} \mathrm{SO}_{4}$. The solvent was completely removed under vacuum. The residue was redissolved in $0.5 \mathrm{~mL}$ pyridine and


trifluoroacetamide containing 1 $\%$ trimethyl-chlorosilane solution and derivatized at $80{ }^{\circ} \mathrm{C}$ for $30 \mathrm{~min}$. The samples were analyzed using an Agilent 7890A gas chromatograph equipped with a capillary column, and a flame ionization detector at $360{ }^{\circ} \mathrm{C}$. The oven 
Mahmud, G. F. ${ }^{1}$; El Ghadban, E.A.E ${ }^{2}$ and Shahat, M. S. ${ }^{3}$ and Gamal Ali El Sharnouby ${ }^{3}$

temperature of the $\mathrm{GC}$ was initially held at $285{ }^{\circ} \mathrm{C}$ for 35 $\mathrm{min}$ and then increased to 310 ${ }^{\circ} \mathrm{C}$, with an increase of 10 ${ }^{\circ} \mathrm{C} / \mathrm{min}$, and kept for $10 \mathrm{~min}$. The carrier gas was helium and the flow rate was $0.5 \mathrm{~mL} / \mathrm{min}$. The sterol composition was identified by comparing retention times of sterols in samples with the standard sterol mixture. The internal standard method was used for quantification.

\section{Triacylglycerol Determination}

The triacylglycerol (TG) composition of the oils was determined according to the official method $0.2 \mathrm{~g}$ oil was weighed and dissolved in $20 \mathrm{~mL}$ $n$-heptane and then transferred into vials. Triacylglycerol composition was analyzed with an Agilent 7820A gas chromatograph equipped with a capillary column, and flame ionization detector at $360{ }^{\circ} \mathrm{C}$.

The oven temperature was initially $285{ }^{\circ} \mathrm{C}$ for $35 \mathrm{~min}$ and then increased at $10{ }^{\circ} \mathrm{C} / \mathrm{min}$ to $310^{\circ} \mathrm{C}$ and kept for $10 \mathrm{~min}$. The carrier gas was helium and the flow rate $0.5 \mathrm{~mL} / \mathrm{min}$. Triacylglycerol compositions were identified by comparing their retention times with those of the standard TAG mixture (Gutfinger, 1981)

\section{Total Phenolic Content}

The total phenolic content was determined using the Folin-Ciocalteu method with minor modifications by Gutfinger, (1981). First, $600 \mu \mathrm{L}$ of methanolic extracts were added to test tubes containing $2.5 \mathrm{~mL}$ Folin-Ciocalteu reagent (diluted $1 \times 10$ ). Contents were mixed thoroughly then after 3 min, $2 \mathrm{~mL}$ of $7.5 \%$ sodium carbonate was added and mixed again. After $2 \mathrm{~h}$ of incubation at room temperature, the absorbance of the mixtures was measured at $765 \mathrm{~nm}$. The phenolic content was calculated according to a standard curve prepared with Gallic acid. The results were expressed as $\mu \mathrm{g}$ Gallic acid equivalents (GAE)/g oil.

\section{Phenolic \\ Determination}

Compound

Phenolic fractions were determined according to Baiano et al., (2013). The methanolic extract was filtered through a 
0.45- $\mu \mathrm{m}$ PTFE membrane filter into the vial and injected into an Agilent HPLC system (Agilent, Kyoto, Japan). A gradient solution including two solvents: (A) $2 \%$ acetic acid in water and (B) methanol: acetonitrile (1:1, $\mathrm{v} / \mathrm{v})$ at constant flow rate of 1 $\mathrm{mL} / \mathrm{min}$ was used to achieve the separation of phenolic compounds. The gradient program of solvent was the following: 100 to $70 \% \mathrm{~A}$ in 30 min, 70 to $50 \% \mathrm{~A}$ in $15 \mathrm{~min}, 50$ to $40 \% \mathrm{~A}$ in $10 \mathrm{~min}, 40$ to $0 \%$ $\mathrm{A}$ in $10 \mathrm{~min}, 0 \%$ for $5 \mathrm{~min}$, and 0 to $100 \% \mathrm{~A}$ in $5 \mathrm{~min}$.

\section{Tocopherols Determination}

Tocopherol isomers of the oils were determined according to the method Turan, et al. , (2007) described by Turan et al. Tocopherol isomers were analyzed using a HPLC system (Agilent, Kyoto, Japan) equipped with Inertsil ODS-3 normal phase column $(250 \times 4.6$ $\mathrm{mm}, 5 \mu \mathrm{m})$ and SPD-M20A photodiode array detector. The tocopherol isomers were identified by comparing their retention times with authentic standards and quantified on the basis of peak areas as compared with the external standards.

\section{Squalene Determination}

Squalene content was determined according to the GC procedure explained in sterol and TG determinations by Gutfinger, (1981) methods. After preparation of unsaponifiable matter, the samples were analyzed with an Agilent $7820 \mathrm{~A}$ GC system by using the same GC operating conditions given for the determination of sterols. The internal standard method was used for quantification of squalene.

\section{Statistical Analysis}

Obtained data of this study were tabulated and statistically analyzed using randomized complete block design according to Snedecor and Cochran, (1967).

\section{RESULTS \& DISCUSSION}

\section{Analytical Parameters of EVOO}

Free Fatty Acid, UV absorption parameters $\left(\mathrm{K}_{232}\right.$ and $\mathrm{K}_{270}$ ) and peroxide value (PV) 
Mahmud, G. F. ${ }^{1}$; El Ghadban, E.A.E ${ }^{2}$ and Shahat, M. S. ${ }^{3}$ and Gamal Ali El Sharnouby ${ }^{3}$

are important quality factors and are generally used for classifying olive oils. Table 1 shows the parameters of the EVOO samples. EU regulation has established a value of FFA $<0.8$ $\%$ for "extra virgin" olive oil (Regulation EC/1989/2003).

As seen in Table 1, significant differences were observed between samples $(p<$ $0.05)$, except for the $K_{232}$ value. FFA values of both samples were below the limit. This could be because of improper fruit harvesting, transport and storage conditions. EU regulations establish a value of $\mathrm{K}_{232}<2.5$ and $K_{270}<0.22$ for extra virgin olive oils (Regulations EC/1989/2003). Both of the samples analyzed showed UV absorbance values much lower than these limits. The peroxide value offers a measure of lipid oxidation. In the all samples PV values were 3.75 and 7.24 mequiv $\mathrm{O}_{2} / \mathrm{kg}$ oil for (NS) and (IS) samples, respectively. The PV of all samples was lower than the legal limit $(\mathrm{PV}<20$ mequiv $\mathrm{O}_{2} / \mathrm{kg} \quad$ oil, EC/1989/2003) established for EVOO. Those quality parameters did not exceed the limits established for the best commercial quality olive oil, designated as "extra virgin olive oil category" (IOC, 2015), by the International Olive Council.

\section{Fatty Acid Compositions}

Fatty acid composition has a wide range depending on genetic and environmental factors and has been used for qualitative assessment of olive oil (Lanza, et al., 1998); (Criado, et al., 2008). Olive oil has a high content of monounsaturated fatty acids important to good nutrition and human health, such as oleic acid (Ozyılkan et al., 2005). The average fatty acid composition, expressed as a percentage of the total fatty acids is summarized in Table 2. The results showed that the distribution of fatty acid composition was within the normal ranges expected for extra virgin olive oil (IOC, 2015).

Significant differences were not observed between samples $(p<0.05)$, except for O/L (O/L: C18:1/C18:2) ratio. Oleic acid (C18:1), linoleic acid (18:2) and palmitic acid (C16:0) were the major fatty acids. Oleic acid was the primary and 
Mahmud, G. F. ${ }^{1}$; El Ghadban, E.A.E ${ }^{2}$ and Shahat, M. S. ${ }^{3}$ and Gamal Ali El Sharnouby ${ }^{3}$

dominant fatty acid in each of the samples. Oleic acid contents of (NS) and (IS)were 65.14 and $63.00 \%$, respectively. (NS) samples had higher oleic acid levels than (IS) samples as seen in the Table 2. Another important unsaturated fatty acid in olive oil is linoleic acid, and linoleic levels of (IS) samples were higher (13.2\%) than (NS) samples $(12.3 \%)$. Palmitic acid is the major saturated fatty acid in olive oil, with levels ranging between 16.32 and $16.96 \%$, according to the cultivars, respectively. Levels of other fatty acids, including palmitoleic (C16:1), margaroleic (C17:1), stearic (C18:0), linolenic (C18:3), arachidic (C20:0) and gadoleic (C20:1) acids were quite low. Fatty acid composition results were in agreement with the findings of other studies on Egypian olive oils (Andjelkovic et al., 2009); (Arslan and Schreiner 2012).

The amounts of total saturated ( SFA), mono unsaturated ( $\mathrm{MUFA}$ ) and polyunsaturated FA (IPUFA) and the oleic/linoleic acid ratio (O/L: C18:1/C18:2) were also evaluated. The $\mathrm{O} / \mathrm{L}$ ratios were
5.2 for (NS) and 4.7 for (IS) samples. This ratio can be useful to characterize olive cultivars and have a marked relationship with stability (Mansouri etal., 2013). For Arbequina cultivars the ratios $\mathrm{O} / \mathrm{L}$ are respectively 8.49 for cultivars grown in Morocco (Carelli, 2008), between 6.02 and 6.67 for cultivars grown in Spain (Morello et al., 2004); (LópezCortés et al., 2013) and 4.26 in Tunisia (Chtourou et al., 2013). But this ratio $(\mathrm{O} / \mathrm{L}=5.25)$ is low (2.05-3.69) for cultivars grown in Argentina (Carelli, 2008), It was observed that (IS) was rich in total SFA, whereas (NS) had a higher level of total MUFA due to its higher level of oleic acid.

As compared to olive oils produced from these varieties when cultivated in their original growing area in Spain (Tous and Romero, 2000), as well as in other countries such as Morocco and Argentina, the oleic acid levels are relatively similar to oils produced in Morocco (Mansouri etal., 2013). However, Arbequina cultivated in Egypt produced lower levels of oleic acid as compared to its original growing 
area. (NS) and (IS) exhibited relatively high levels of linoleic acid and levels of palmitic acid similar to its original growing area (Tous and Romero, 2000).

\section{TG Compositions}

TG is an important indicator of the quality and purity of olive oils. It is increasingly used by the food industry to confirm authenticity, because of the specificity of the triacylglycerol composition in different kinds of fats and oils (Mansouri et al., 2013).

The mean values of TG for olive oils are shown in Table 3. In the study, ten $\mathrm{TG}$ were identified. The oils are characterized by four primaries TG: triolein (OOO), dioleopalmitin (POO), dioleolinolein (LOO), PLO and six secondary TAG: PPO, LOL, SOO, LPL, POP and POLn which were present at a low percentage.

For the studied olive oils, OOO, POO, PLO and LOO constitute the most representative TG, although their percentages vary greatly. Statistical differences $(p<0.05)$ were found between cultivars in terms of TG content. Triolein (OOO) was the major TG within all the TG and its content in the samples ranged from 25.27 to $31.69 \%$. The presence of a high level of 1,2,3-trioleylglycerol (OOO) in olive oil constitutes a favorable authenticity indicator. The second major TG was POO with levels of 28.2 and 31.5 for (NS) And (IS), respectively. Both olive oil samples had low levels of LLL, with 0.46 and 0.32 , respectively. The level of LLL of all samples did not exceed $0.5 \%$, which is the maximum limit according to EU regulation for olive oils. These results indicated that TAG composition of olive oils showed great variability between different growing areas, and also showed great variability between oils, as studied (Tous and Romero, 2000) ; (Gokcebag et al. 2013).

Triolein contents of the olive oils were lower than reported for Spanish and Tunisian cultivars, while POO was higher than these compared olive oils (Mansouri etal., 2013). 


\section{Sterol Compositions}

A table 4, Sterols is constituents of the unsaponifiable fraction of fats and oils, including olive oil and is very important nutritional and authenticity parameters. They are also characteristic of the identity and purity of vegetable oils (Chtourou et al., 2013) and can be used to detect adulteration (Ranalli et al., 2002).

Study showed that Arbequina grown in the Egypt had a higher value for phenolic compounds $(45.68 \mu \mathrm{g} / \mathrm{kg})$. (NS) had TPC levels than (NS) and (IS) olive oils as well as some Spanish samples (Carelli, 2008); (Bakhouche etal., 2013); (López-Cortés etal., 2013); (Franco et al., 2014). However, TPC of the Ramicilla variety studied by Carelli, (2008); Benito et al., (2010), had a higher value $(831.33 \mu \mathrm{g} / \mathrm{kg}$ ) than (NS), whereas Negral variety was very close to the result of (NS) with a level of $45.68 \mu \mathrm{g} / \mathrm{kg}$. Moreover, according to the study of Pardo, et al., (2013) Cornicabra and Picual varieties also had quite higher TPC than (NS) samples at levels of 7980 and $8030 \mu \mathrm{g} / \mathrm{kg}$, respectively. TPC of olive oils from economically were studied by some researchers, Ocakoglu et al., (2009); Ilyasoglu et al., (2010) and TPC content of (NS) (45.68 $\mu \mathrm{g} / \mathrm{kg}$ ) was found to be quite higher than the findings of these researchers.

\section{Tocopherol Content}

Tocopherols are the main lipid-soluble antioxidants present in olive oil. Of the four isomers found in olive oil $(\alpha, \beta$, $\gamma$ and $\delta$ ) $\alpha$ (vitamin $E$ ) is the most abundant (90-95\%). The concentration of these compounds in olive oil range was between 150 and $250 \mathrm{mg} / \mathrm{kg}$ (Amelio, 2003). In this study, the quality characterization of the different monovarietal EVOO has been studied by quantifying their tocopherol content. Table 5, was represents $\alpha, \quad \beta, \quad \gamma$ and $\delta$-tocopherol fractions and total tocopherol content (TTC) of olive oils.

The levels of $\alpha$ tocopherol and total tocopherol in the analyzed oils showed significant differences $(p<0.05)$ between the growing areas of the cultivars, as seen in Table 5 . 
Mahmud, G. F. ${ }^{1}$; El Ghadban, E.A.E ${ }^{2}$ and Shahat, M. S. ${ }^{3}$ and Gamal Ali El Sharnouby ${ }^{3}$

Differences in total tocopherol content may also be related to variations in climatic conditions as known high amounts of rainfall result in higher levels of tocopherol in olives (Ilyasoglu et al., 2010).

The major tocopherol was $\alpha$-tocopherol with a content ranging from 179.55 to 202.50 $\mathrm{mg} / \mathrm{kg}$ for (NS) and (IS), respectively (Table 5). Consistent with the $\alpha$-tocopherol content, (NS) was richest in total tocopherol with $228.70 \mathrm{mg} / \mathrm{kg}$ while this value was 203.85 $\mathrm{mg} / \mathrm{kg}$ for (NS). The level of $\alpha-$ tocopherol of olive oils from was similar to the $\alpha$-tocopherol content of (NS) and (IS), (Ilyasoglu et al., 2010) and some olive oils from Arbequina produced in Spain [(LópezCortés et al., 2013) ; Pardo, et al. , 2013)]. However, these values were less than olive oil of this variety cultivated in Argentina and Tunisia [(Torres and Maestri 2006); (Carelli, 2008); (Guerfel et al., 2012); (Chtourou et al., 2013)].

\section{Phenolic Content and} Antioxidant Capacity
Phenolic, which are present in olive oil in appreciable quantities (50-500 $\mathrm{mg} / \mathrm{kg}$ ), have an important role in the stability of the oil against oxidation. The process of refining removes them almost totally (Amelio, 2003). Phenolic content is one of the most important parameters for evaluation of extra virgin olive oil quality, because phenols widely contribute to oil sensory properties and aroma, which are bitterness and astringency, and they prevent it from oxidation (Bendini et al. , 2007) ; (Mansouri et al. , 2013). In the present study, total phenolic contents (TPC) were determined according to the Folin-Ciocalteu colorimetric method (Gutfinger T, 1981). Table 6 shows the total phenolic content of (NS) and (IS) samples. In addition, individual phenolic fractions were also given in Table 6 .

As shown in Table 6, TPC of the analyzed oils showed significant differences $(p<0.05)$ according to the growing area of the cultivars. (NS) oils showed a higher value for TPC (454.68 $\mu \mathrm{g} / \mathrm{kg})$ whereas the (NS) $(50.86$ $\mu \mathrm{g} / \mathrm{kg}$ ) was less than $100 \mathrm{mg} / \mathrm{kg}$. 
Mahmud, G. F. ${ }^{1}$; El Ghadban, E.A.E ${ }^{2}$ and Shahat, M. S. ${ }^{3}$ and Gamal Ali El Sharnouby ${ }^{3}$

The studies of Garcia et al., (2010) ; Pardo, et al., (2013) reveal considerable quantitative differences in phenolic compounds content among the oils obtained from Arbequina cultivars planted in Spain which showed a total phenol level of $244 \mu \mathrm{g} / \mathrm{kg}$. Results of this study showed that Arbequina grown in Egypt had a higher value for phenolic compounds $(45.68 \mu \mathrm{g} / \mathrm{kg})$. (NS) had TPC levels than Tunisian and Argentina olive oils as well as some Spanish samples (Carelli, 2008) ; (Bakhouche et al., 2013) ; (López-Cortés et al., 2013); (Franco et al. , 2014). However, TPC of the Ramicilla variety studied Benito et al. , (2010) ; Pardo, et al. , (2013) had a higher value $(831.33 \mu \mathrm{g} /$ $\mathrm{kg}$ ) than (NS), whereas Negral variety was very close to the result of (NS) with a level of $45.68 \mu \mathrm{g} / \mathrm{kg}$. Moreover, according to the study of Pardo, etal., (2013) Cornicabra and Picual varieties also had quite higher TPC than (NS) samples at levels of 7980 and $8030 \mu \mathrm{g} / \mathrm{kg}$, respectively. TPC of olive oils from economically important olive cultivars Ismailia and Sinai were studied by some researchers, Ocakoglu et al., (2009),. Ilyasoglu et al., (2010) and TPC content of (NS) (45.68 $\mu g / \mathrm{kg}$ ) was found to be quite higher than the findings of these researchers.

The amount and composition of the phenolic fraction are related to the olive cultivar and the agricultural method (Ilyasoglu et al., 2010); (Bakhouche et al., 2013). Quantitative determination of phenolic compounds in oil is usually performed according to the Folin Ciocalteu colorimetric method. However, this method is not specific, as it gives no indication of the nature of the phenolic compounds present. For this reason separation and identification of individual phenolic compounds have been performed using an LC-MS/MS system. As shown in Table 6, three main phenolic compounds were identified from the two EVOO. The comparative phenolic profiles evaluated by LC-MS/MS of oils produced from the two different growing areas revealed that the main phenolic alcohols in samples from Arbequina were 
Mahmud, G. F. ${ }^{1}$; El Ghadban, E.A.E ${ }^{2}$ and Shahat, M. S. ${ }^{3}$ and Gamal Ali El Sharnouby ${ }^{3}$

hydroxytyrosol, tyrosol and caffeic acid. However, although pcumaric, syringic and ferulic acid were detected in trace amounts, they were not given in Table 6. The concentration of hydroxytyrosol was higher in (NS) $(18.70 \mu \mathrm{g} / 100 \mathrm{~g})$ than in (IS) $(14.65 \mu \mathrm{g} / 100 \mathrm{~g})$. Similarly, a higher content of tyrosol was observed in (NS) $(4.35 \mu \mathrm{g} / 100$ g) than the was $2.51 \mu g / 100 \mathrm{~g}$ found in (IS) . Caffeic acid levels were quite similar to each other at levels of 20.92 and $20.94 \mu g / 100 \quad g$, respectively. Hydroxytyrosol and tyrosol contents of olive oils belong to Ismailia and Sinai cultivars have already been studied (Ilyasoglu et al., 2010). When comparing the studied samples with results of the Ilyasoglu, (NS) and (IS), their oils were richer in phenolic compounds than our samples.

The results of the antioxidant capacity and free radical scavenging properties of the two studied olive oils were evaluated by ABTS, DPPH and ORAC (Oxidation-Reduction Absorbance Capacity) methods and are summarized in Table 7. Statistical differences $(p<0.05)$ were found between cultivars grown in different areas in terms of antioxidant capacity tests. Three different antioxidant tests were conducted: ABTS, DPPH (for quantifying the antiradical activity) based on the abilities of the antioxidants present into extracts to scavenge the radical in comparison with that of a standard antioxidant (Baiano et al. , 2013), and ORAC, which measures antioxidant inhibition of peroxyl-radical induced oxidations (Karadag et al., 2009). Within all the antioxidant activity tests, (NS) had the highest values with levels of $551.38 \mu \mathrm{g}$ Trolox/g oil (ABTS), $536.44 \mu \mathrm{g}$ Trolox/g oil (DPPH) and $503.67 \mu \mathrm{mol} / 100 \quad \mathrm{~g}$ oil (ORAC), while(IS)had lower levels of $198.94 \mu \mathrm{g}$ Trolox/g oil, $54.69 \mu \mathrm{g}$ Trolox/g oil and 272.49 $\mu$ mol Trolox/100 g oil, respectively. The higher antioxidant capacity of (NS) can be explained by the higher content of total phenols.

Correlations between total phenolic content and antioxidant activity were evaluated. The correlation coefficient between total phenolic content and antioxidant activity measured by the ABTS, 
Mahmud, G. F. ${ }^{1}$; El Ghadban, E.A.E ${ }^{2}$ and Shahat, M. S. ${ }^{3}$ and Gamal Ali El Sharnouby ${ }^{3}$

DPPH and ORAC assays was the same $\left(R^{2}=1, p \backslash 0.05, n=2\right)$.

Phenolic content is an important parameter in the evaluation of the extra EVOO quality because phenolic compounds protect the TAG from oxidation and contribute to oil flavor and aroma (Karadag et al., 2009). In addition, it was reported that a high total phenolic content appears to be beneficial for the shelf life of the oil (Dabbou etal., 2010); (Chtourou et al., 2013).

\section{Other Minor Compounds (Squalene, Chlorophyll, Carotenoid Content)}

Squalene (C30) is an important intermediary for biological synthesis of sterols, and is present in concentrations of about $1500-2000 \mathrm{mg} / \mathrm{kg}$ in olive oil (Amelio, 2003). Shark and whale liver oil are the primary commercial sources of squalene (Ghimire et al., 2009). The other sources are olive oil, wheat germ and rice bran oils. There is limited information on the squalene value of Egyptian olives. Olive oil is an important squalene source and is evaluated from this respect. The squalene levels of the two studied olive oils evaluated by GC-FID are summarized in Table 8.

Squalene levels varied from 1526.36 to $3494.68 \mathrm{mg} / \mathrm{kg}$ for (NS) and

respectively.(IS) was quite rich in squalene content. Although, there is no reliable comparable result in the literature for squalene levels of olive oil from other Arbequina cultivars cultivated in different geographical areas, our findings on the squalene content of (IS) were in accordance with those of Egyptian olive oils studied Duraman, (2010), whereas (NS) was found to have lower levels of squalene. The differences in squalene levels are thought to be due to geographic conditions.

Chlorophylls and carotenoids are the main lightharvesting pigments found in vegetable oils Also, they are important for the prevention of auto-oxidation and photooxidation (Chtourou etal., 2013). $\beta$-Carotene (C40), which imparts a characteristic yelloworange color to the oil, is a precursor of vitamin A. Its concentration in olive oils is about 300-400 $\mathrm{mg} / \mathrm{kg}$. 
Mahmud, G. F. ${ }^{1}$; El Ghadban, E.A.E ${ }^{2}$ and Shahat, M. S. ${ }^{3}$ and Gamal Ali El Sharnouby ${ }^{3}$

Chlorophylls are present in olive oils and are responsible for the greenish coloration of certain olive oils. These pigments are also important factors in olive oil stability (Chtourou et al., 2013). Table 8 represents $\beta$ carotene and chlorophylla levels of olive oils. Significant differences in the levels of chlorophylla in the analyzed oils were observed $(p<0.05)$, while no significant difference was observed in the $\beta$-carotene content. Levels of chlorophylla pigment varied between 0.52 $\mathrm{mg} / \mathrm{kg}$, in (NS) and $0.64 \mathrm{mg} / \mathrm{kg}$ in the (IS). The content of $\beta$ carotene was similar with levels of about $0.20 \mathrm{mg} / \mathrm{kg}$ in both the samples. When comparing our results with the studies of Chtourou etal. (2013) and Lopez-Cortes etal (2013). Olive oils from this cultivar in Tunisia and Spain had higher chlorophylla and $\beta$-carotene content.

\section{CONCLUSION}

Oil produced from the Spanish Arbequina olive cultivar, when grown in Egypt under climatic and environmental conditions similar to Spain, has some compositional differences than when grown in its native Spain and other parts of the world. In particular, Arbequina EVOO produced in Egypt showed considerable deviations when compared to same cultivars cultivated in different parts of the world with respect to compositions of TAG, phenolics, tocopherols and sterols. The geographic area appears to have a significant effect on the qualitative characteristics and the chemical composition of olive oil. Oil from Arbequina has a composition in fatty acid close to that of economically important varieties of Egypt, Ismailia and Sinaicultivars, but at the same time there was great statistically

significant difference in TAG composition, phenolic content and antioxidant activity.

Egypt, especially the North Sinai Governorate (NS) of Egypt, could be a quite adaptable area to yield good quality Arbequina olives and thus to produce olive oils from Arbequina varieties. The knowledge about the oil composition from the olives 
grown in areas near the Mediterranean region will contribute to the updating of market conditions and the review of international rules affecting trade in olive oils.

\section{REFERENCES}

\section{Amelio M (2003):}

Chemical-physical characteristics of olive oils. Technical course for olive oil testers. organization nazionaale assaggiatori olio di olivia. J food sci 22:120 121

\section{Andjelkovic M; Acun S. Van - Hoed VR and Van Camp J (2009):}

Chemical composition of turkish olive oil-ayvalik. J am oil chem soc 86:135140 Antioxidant activity of extra-virgin olive oils. $J$ Am Oil Chem soc 90:103-111

\section{AOCS (2002):}

Official methods of analysis of AOAC international. 17th ed.; Gaithersburg.

\section{AOCS (1998):}

Official methods and recommended practices of the American Oil Chemists' Society, The 16th Ed., Maryland

Arslan D and Schreiner M (2012):

Chemical characteristics and anti-oxidant activity of olive oils from turkish varieties grown in hatay province. Sci hortic 144:141-152

\section{Baiano A; Terracone C;}

Viggiani I; Del Nobile MA (2013):

Effects of cultivars and location on quality, phenolic content and antioxidant activity of extravirgin olive oils. J Am Oil Chem

Bakhouche A; lozano-Sánchez Jj; Beltrán-Debón R; Joven J; Segura-Carretero $A$ and Fernández-Gutiérrez A (2013): Phenolic characterization and geographical classification of commercial arbequina extra-virgin olive oils produced in southern 
Mahmud, G. F. ${ }^{1}$; El Ghadban, E.A.E ${ }^{2}$ and Shahat, M. S. ${ }^{3}$ and Gamal Ali El Sharnouby ${ }^{3}$

catalonia. Food res int 50:401-408

Barranco D; FernandezEscobar R and Rallo L (1999):

Variedades y patrones in el cultivo del olivo, ediciones mundiprensa 61-89

\section{Bendini A; Cerretani L;} Carrasco-Pancorbo A;

Gómez-Caravaca Aam;

Segura- Carretero A; and Lercker G (2007):

Phenolic molecules in virgin olive oils: a survey of their sensory properties, health effects, antioxidant activity and analytical methods. An overview of the last decade. Molecules 12:1679

Benito $M$; Oria $\mathbf{R}$ and Sánchez-Gimeno AC (2010):

Characterization of the olive oil from three potentially interesting varieties from aragon (spain). Food Sci Tech int 16(6):0523-0528

Bondet V; Brand-Williams W and Berset $C$ (1997):
Kinetics and mechanism of antioxidant action using the dpph free radical method. Lwt-Food Sci Technol 30:609-615

Carelli AA (2008):

Olive oil chemistry in Argentina, Planta Pilotode Ingeniera Quimica, Bahia Blanca

Chtourou M; Gargouri B; Jaber H; Abdelhedi $\mathbf{R}$ and Bouaziz M (2013):

Comparative study of olive oil quality from chemlali sfax versus arbequina cultivated in tunisia. Eur $j$ lipid sci technol 115:631640

\section{Criado MN; Romero MP;} Casanovas $M$ and Motilva MJ (2008):

Pigment profile and colour of monovarietal virgin olive oils from arbequina cultivar obtained during two consecutive crop seasons. Food chem 110:873-880

Dabbou S; Brahmi F; Taamali $A$ and Issaoui M (2010): 
Mahmud, G. F. ${ }^{1}$; El Ghadban, E.A.E ${ }^{2}$ and Shahat, M. S. ${ }^{3}$ and Gamal Ali El Sharnouby ${ }^{3}$

Extra virgin olive oil components and oxidative stability from olives grown in tunisia. $J$ am oil chem soc 87:1199-1209

\section{Diraman H (2010):}

Characterization by chemometry of the most important domestic and foreign olive cultivars from the national olive collection orchard of Turkey. Grasas aceites 61(4):341-351

Franco MN; Galeano-Díaz T; López O; FernándezBolaños JG; De Miguel C; Gil MV and MartínVertedor D (2014):

Phenolic compounds and antioxidant capacity of virgin olive oil. Food chem 163:289-298

\section{Garcia-Gonzalez D; Rowoeo} $\mathrm{N}$ and Rawm A (2010):

Comparative study of virgin olive quality from varieties cultivated in Chilie and Spain. J agric food chem 58:12899 12905
Ghanbari R; Anwar F; Alkharfy KM; Gilani AH and Saari N (2012):

Valuable nutrients and functional bioactives in different parts of olive (olea europaea 1.). Int $J$ mol sci 13:3291-3340

Ghimire GP; Lee HC and Sohng JK (2009):

Improved squalene production via modulation of the methylerythritol 4phosphate pathway and heterologous expression of genes from streptomyces peucetius atcc 27952 in escherichia coli. Appl environ microbiol 75:7291-7293

\section{Gokcebag M; Diraman $\mathbf{H}$ and Ozdemir D (2013):}

Classification of turkish monocultivar (Ismailia and Sinaicv.) Virgin olive oils from north and south zones of aegean region based on their triacyglycerol profiles. J Am oil chem soc 90:16611671 
Mahmud, G. F. ${ }^{1}$; El Ghadban, E.A.E ${ }^{2}$ and Shahat, M. S. ${ }^{3}$ and Gamal Ali El Sharnouby ${ }^{3}$

\section{Gorinstein S; Martin-Belloso}

O; Katrich E and Lojek A (2003):

Comparison of the contents of the main biochemical compounds and the antioxidant activity of some spanish olive oils as determined by four different radical scavenging tests. $J$ nutr biochem 14:154-159

\section{Guerfel M; Ben Mansour M;}

Ouni Y; Boujnah D and Zarrouk M (2012):

Compositional quality of virgin olive oils from cultivars introduced in two tunisian locations. Afr $j$ agric res 7(16):2469-2474

\section{Gutfinger T (1981):}

Polyphenols in olive oils. $J$ Am oil chem soc 58:966968

Haddada FM; Krichène D; Manai H; Oueslati I; Daoud D and Zarrouk M (2008):

Analytical evaluation of six monovarietal virgin olive oils from northern tunisia. Eur $j$ lipid sci technol 110:905-913
Huang D; Ou B; HampschWoodill M; Flanagan JA and Deemer EK (2002):

Development and validation of oxygen radical absorbance capacity assay for lipophilic antioxidants using randomly methylated â-cyclodextrin as the solubility enhancer. $J$ agric food chem 50:1815-1821

\section{Ilyasoglu H; Ozcelik B; Hoed}

VV and Verhe R (2010):

Characterize of Aegean

olive oils by their minor compounds. J Am Oil Chem Soc 87:627-636

Io C (2015):

Trade standard applying to olive oils and olive pomace oils. International olive council, coi/t.15/nc no 3/rev. 8

Karadag A; Ozcelik B and Saner S (2009):

Review of methods to determine antioxidant capacities. Food anal methods 2:41-60

Lanza CM; Russo C; Tomaselli F (1998): 
Mahmud, G. F. ${ }^{1}$; El Ghadban, E.A.E ${ }^{2}$ and Shahat, M. S. ${ }^{3}$ and Gamal Ali El Sharnouby ${ }^{3}$

Relationship between geographical origin and fatty acid composition of extra-virgin olive oils produced in three areas of eastern Sicily, Italy. $J$ food sci 4:359-366

Lazzez A; Perri E; Anna CM; Cossentini $M$; Khlif $M$ and Cossen-Tini M (2008):

Influence of olive maturity stage and geographical origin on some minor components in virgin olive oil of the chemlali variety. $J$ Agric Food Chem 56:982988

López-Cortés I; SalazarGarcía DC; Velázquez-Martí $B$ and Sala-Zar DM (2013):

Chemical characterization of traditional varietal olive oils in east of Spain. Food res int 54(2):1934-1940

\section{Lozano-Sánchez J; Cerretani}

\section{L; Bendini A; Segura-} Carretero A and FernándezGutiérrez A (2010):

Filtration process of extra virgin olive oil: effect on minor components, oxidative stability and sensorial and physicochemical characteristics. Trends food sci technol 21:201-211

Mansouri F, Ben moumen A, Lopez G, Fauconnier M, Sindic M, Serghini-Caid H, Elamrani A, 2013.

Preliminary

Characterization of monovarietal virgin olive oils produced in eastern area of Morocco. Inside Food Symposium. 9-12 April 2013, Leuven, Belgium, pp: 9-12.

Morello JR; Motilva MJ; Tovar MJ and Romero MP (2004):

Changes in commercial virgin olive oil (cv. Arbequina) during storage, with special emphasis on the phenolic fraction. Food chem 85:357-364

\section{Ocakoglu D; Tokatli F; Ozen} $B$ and Korel F (2009):

Distribution of simple phenols, phenolic acids and flavonoids in turkish monovarietal extra virgin olive oils for two harvest years. 
Mahmud, G. F. ${ }^{1}$; El Ghadban, E.A.E ${ }^{2}$ and Shahat, M. S. ${ }^{3}$ and Gamal Ali El Sharnouby ${ }^{3}$

Food chem 113:401-410

Origin on some minor components in virgin olive oil of the chemlali variety. $J$ agric food chem 56:982988

\section{Ozyilkan O; Colak D; Akcali} $\mathrm{Z}$ and Basturk $\mathrm{B}(\mathbf{2 0 0 5 )}$ :

Olive: fruit of peace against cancer. Asian pacific $j$ cancer prev 6(1):77-82

Pardo JE; Sena E, Cuesta MA; Granell JD; Valiente J and Alvarez-Orti M (2013):

Evaluation of potential and real quality of virgin olive oil from "campos de hellín" (albacete, spain). J Am oil chem soc 90:851-862

\section{Pereira JA; Pereira APG;} Ferreira IGFR and Valentap $P$ (2006):

Table olives from portugal; phenolic compounds, antioxidant potential and antimicrobial activity. $J$ agric food chem 54:84258431

Petrakis P; Agiomyrgianaki A; Christophoridou S; Spyros A and Dais P (2015):
Geographical

characterization of greek virgin olive oils (cv. Koroneiki) using $1 \mathrm{H}$ and 31PNMR fingerprint-ing with canonical discriminant analysis and classification binary trees. $J$ agric food chem 56:3200-3207

\section{Ranalli A; pollastri L; contento $S$ and Di Loreto $G$ (2002):}

Sterol and alcohol components of seeds, pulp, and whole olive fruit oils. Their use to characterise olive fruit variety by multivariates. $J$ sci food agric 82:854-859

\section{Re R; Pellegrini N;} Proteggente A; Pannala A; Yang $M$ and Rice-Evans $C$ (1999):
Antioxidant
activity applying an improved abts radical cation decolorization assay. Free radic biol med 26:1231-1237

Rodney JM; Ayton $J$ and Graham K (2014):

The influence of growing region, cultivar and harvest 
timing on the diversity of australian olive oil. $J$ Am oil chem soc 87:877-884

\section{Romero MP; Tovar MJ; Ramo}

$T$ and Motilva MJ (2003):

Effect of crop season on the composition of virgin olive oil with protected designation of origin "les garrigues". J Am oil chem soc 80:423-431

\section{Sendecor GW and Cochran W.C (1997):}

Statistical Methods, $7^{\text {th }}$ Ed. Oxford and J.B.H. Publishing Co.,504.

\section{Torres MM and Maestri DM} (2006):

Chemical composition of arbequina virgin olive oil in relation to extraction and storage conditions. $J$ sci food agric 86:2311-2317

Tous J and Romero A (2000):

Fiche a varietal del cultivar "arbequina". Olivae 43(10):28-29

\section{Tura D; Gigliotti C; Pedo S;} Failla O; Bassi D and Serraiocco A (2007):
Influence of cultivar and site of cultivation on levels of lipophilic and hydrophilic antioxidants in virgin olive oils (olea europea 1.) And correlations with oxidative stability. Sci hortic 112:108-119

\section{Turan S; Topcu A; Karabulut} I; Vural $H$ and Hayaloglu AA(2007):

Fatty acid, triacylglycerol, phytosterol, and tocopherol variations in kernel oil of malatya apricots from Spain. J agric food chem 55:10787-10794

Verleyen T; Forcades M; Verhé R; Dewettinck K; Huyghebaert A and De Greyt W (2002):

Analysis of free and esterified sterols in vegetable oils. $J$ Am oil chem soc 79 (2):117-122 
Physicochemical and phytonutrients Evaluation of Arbequina Extra Virgin Olive oil Cultivated Recently in Egypt

Mahmud, G. F. ${ }^{1}$; El Ghadban, E.A.E ${ }^{2}$ and Shahat, M. S. ${ }^{3}$ and Gamal Ali El Sharnouby ${ }^{3}$

Table 1 : Some chemical characteristics of Arbequina EVOO

\begin{tabular}{|c|c|c|}
\hline \multirow{2}{*}{$\begin{array}{l}\text { Physicochemical } \\
\text { parameter }\end{array}$} & \multirow[t]{2}{*}{ (NS) } & \multirow[t]{2}{*}{ (IS) } \\
\hline & & \\
\hline UV270 & $0.14 \pm 0.00^{\mathrm{a}}$ & $0.11 \pm 0.00^{b}$ \\
\hline UV232 & $0.73 \pm 0.04^{\mathrm{ns}}$ & $0.76 \pm 0.00^{\mathrm{ns}}$ \\
\hline $\mathrm{PV}\left(\right.$ meq $\left.\mathrm{O}_{2} / \mathrm{kg}\right)$ & $3.75 \pm 0.03^{\mathrm{a}}$ & $7.24 \pm 0.05^{b}$ \\
\hline $\begin{array}{l}\text { Free Acidity }(\% \\
\text { oleic acid })\end{array}$ & $0.75 \pm 0.05^{\mathrm{a}}$ & $0.34 \pm 0.03^{b}$ \\
\hline$L$ & $3.88 \pm 0,01^{\mathrm{a}}$ & $14.69 \pm 1.13^{\mathrm{a}}$ \\
\hline$a$ & $0.35 \pm 0.00^{\mathrm{a}}$ & $2.98 \pm 0.70^{\mathrm{a}}$ \\
\hline$b$ & $7.46 \pm 0.24^{\mathrm{a}}$ & $24.8 \pm 2.25^{\mathrm{a}}$ \\
\hline
\end{tabular}

Significant differences in the same row are shown by symbol $(\mathrm{a}-\mathrm{b})(p<0.05)$ $P V$ peroxide number, $F F A$ free fatty acidity as $\%$ oleic acid $n s$ no significance

Table 2 : Fatty acid composition of Arbequina EVOO samples

\begin{tabular}{|l|l|l|}
\hline Fatty acids & \multicolumn{1}{|c|}{$(\mathrm{NS})(\%)$} & \multicolumn{1}{|c|}{$(\mathrm{IS})(\%)$} \\
\hline Palmitic $(\mathrm{C} 16: 0)$ & $16.32 \pm 0.66$ & $16.96 \pm 0.02$ \\
\hline Palmitoleic $(\mathrm{C} 16: 1)$ & $2.17 \pm 0.48$ & $2.57 \pm 0.00$ \\
\hline Stearic $(\mathrm{C} 18: 0)$ & $1.85 \pm 0.01$ & $1.87 \pm 0.00$ \\
\hline Oleic $(\mathrm{C} 18: 1)$ & $65.14 \pm 2.16$ & $63.00 \pm 0.02$ \\
\hline Linoleic $(\mathrm{C} 18: 2)$ & $12.36 \pm 0.92$ & $13.28 \pm 0.00$ \\
\hline Linolenic $(\mathrm{C} 18: 3)$ & $0.35 \pm 0.01$ & $0.36 \pm 0.00$ \\
\hline Arachidonic (C20:0) & $0.59 \pm 0.02$ & $0.61 \pm 0.00$ \\
\hline Eicosenoic (C20:1) & $0.27 \pm 0.01$ & $0.27 \pm 0.00$ \\
\hline Behenic $(\mathrm{C} 22: 0)$ & $0.30 \pm 0.05$ & $0.35 \pm 0.00$ \\
\hline$\Sigma$ SFA & $19.08^{\mathrm{a}}$ & $20.32^{\mathrm{b}}$ \\
\hline$\Sigma$ MUFA & $67.5^{\mathrm{a}}$ & $65.58^{\mathrm{b}}$ \\
\hline$\Sigma$ PUFA & $12.95^{\mathrm{a}}$ & $13.89^{\mathrm{b}}$ \\
\hline O/L ratio & $5.2^{\mathrm{a}}$ & $4.7^{\mathrm{b}}$ \\
\hline
\end{tabular}

Significant differences in the same row are shown by different letters $(a-b)$ varieties $(p$ $<0.05)$

SFA saturated fatty acid, MUFA monounsaturated fatty acid, PUFA polyunsaturated fatty acid, O/L oleic/linoleic ratio ns non significant 
Physicochemical and phytonutrients Evaluation of Arbequina Extra Virgin Olive oil Cultivated Recently in Egypt

Mahmud, G. F. ${ }^{1}$; El Ghadban, E.A.E ${ }^{2}$ and Shahat, M. S. ${ }^{3}$ and Gamal Ali El Sharnouby ${ }^{3}$

Table 3 : TAG composition of Arbequina EVOO samples

\begin{tabular}{|c|c|c|}
\hline TAG & $(N S)(\%)$ & $(I S)(\%)$ \\
\hline PPO & $6.58 \pm 0.12^{\mathrm{a}}$ & $8.66 \pm 0.71^{\mathrm{b}}$ \\
\hline PPL & $3.42 \pm 0.07^{\mathrm{a}}$ & $5.30 \pm 0.12^{\mathrm{b}}$ \\
\hline POS & $1.18 \pm 0.01$ & $1.18 \pm 0.16$ \\
\hline POO & $28.21 \pm 0.12^{\mathrm{a}}$ & $31.54 \pm 1.54^{\mathrm{b}}$ \\
\hline PLO & $11.61 \pm 0.08^{\mathrm{a}}$ & $14.14 \pm 0.77^{\mathrm{b}}$ \\
\hline SOO & $2.82 \pm 0.04$ & $2.00 \pm 0.24$ \\
\hline OOO & $31.69 \pm 0.64^{\mathrm{a}}$ & $25.27 \pm 0.50^{\mathrm{b}}$ \\
\hline OLO & $11.45 \pm 0.28$ & $9.20 \pm 1.37$ \\
\hline LLO & $1.57 \pm 0.25$ & $1.84 \pm 0.29$ \\
\hline LLL & $0.46 \pm 0.05^{\mathrm{a}}$ & $0.32 \pm 0.00^{\mathrm{b}}$ \\
\hline Others & $1.03 \pm 0.99^{\mathrm{a}}$ & $0.58 \pm 0.54^{\mathrm{b}}$ \\
\hline
\end{tabular}

Significant differences in the same row are shown by symbol $(a-b)(p<0.05)$

Ns= no significance

Table 4: Sterol composition and some chemical characteristics of Arbequina EVOO

\begin{tabular}{|l|c|c|}
\hline Sterols & $(\mathrm{NS})(\%)$ & $(\mathrm{IS})(\%)$ \\
\hline Campesterol & $3.15 \pm 0.02 \mathrm{a}$ & $1.95 \pm 0.04 \mathrm{~b}$ \\
\hline Stigmasterol & $0.58 \pm 0.02 \mathrm{a}$ & $1.75 \pm 0.04 \mathrm{~b}$ \\
\hline$\beta$-Sitosterol & $81.30 \pm 0.70 \mathrm{a}$ & $76.46 \pm 0.65 \mathrm{~b}$ \\
\hline $\begin{array}{l}\Delta 5- \\
\text { Avenasterol }\end{array}$ & $13.72 \pm 0.17 \mathrm{a}$ & $18.57 \pm 0.58 \mathrm{~b}$ \\
\hline
\end{tabular}

Significant differences in the same row are shown by different lower case letters $(a-b)$ $(p<0.05) \quad n s=$ no significance 
Physicochemical and phytonutrients Evaluation of Arbequina Extra Virgin Olive oil Cultivated Recently in Egypt

Mahmud, G. F. ${ }^{1}$; El Ghadban, E.A.E ${ }^{2}$ and Shahat, M. S. ${ }^{3}$ and Gamal Ali El Sharnouby ${ }^{3}$

\section{Table 5 : Tocopherol content of Arbequina EVOO}

\begin{tabular}{|l|l|l|}
\hline $\begin{array}{l}\text { Tocopherol } \\
\text { fractions } \\
\text { contents }\end{array}$ and & (NS) (mg/kg) & (IS) (mg/kg) \\
\hline Tocopherols & $179.55 \pm 4.69 \mathrm{a}$ & $202.50 \pm 11.46 \mathrm{~b}$ \\
\hline$\alpha$-Tocopherol & $9.49 \pm 0.10 \mathrm{a}$ & $9.84 \pm 0.59 \mathrm{a}$ \\
\hline$\beta$-Tocopherol & $11.60 \pm 2.14 \mathrm{a}$ & $13.14 \pm 1.98 \mathrm{a}$ \\
\hline$\gamma$-Tocopherol & $3.18 \pm 0.60 \mathrm{a}$ & $3.19 \pm 0.60 \mathrm{a}$ \\
\hline$\delta$-Tocopherol & $203.85 \pm 1.26 \mathrm{a}$ & $228.70 \pm 5.51 \mathrm{~b}$ \\
\hline TTC &
\end{tabular}
* Significant differences in the same row are shown by different lower case letters $(a-b)$
$(p<0.05) \quad n s-=$ no significance

Table 6: Phenolic composition, of Arbequina EVOO

\begin{tabular}{|l|c|c|}
\hline Phenolics & $\begin{array}{l}(\mathrm{NS}) \\
(\mu \mathrm{g} / 100 \mathrm{~g} \text { oil })\end{array}$ & $\begin{array}{l}(\mathrm{IS}) \\
(\mu \mathrm{g} / 100 \mathrm{~g} \text { oil })\end{array}$ \\
\hline Hydroxytyrosol & $18.70 \pm 0.12^{\mathrm{a}}$ & $14.65 \pm 0.03^{\mathrm{b}}$ \\
\hline Tyrosol & $4.35 \pm 0.41^{\mathrm{a}}$ & $2.51 \pm 0.05^{\mathrm{b}}$ \\
\hline Caffeic acid & $20.92 \pm 0.00^{\mathrm{ns}}$ & $20.94 \pm 0.00^{\mathrm{ns}}$ \\
\hline TPC $(\mu \mathrm{g}$ gallic acid & $45.68 \pm 3.10^{\mathrm{a}}$ & $50.86 \pm 4.13^{\mathrm{b}}$ \\
\hline
\end{tabular}

Significant differences in the same row are shown by different lower case letters $(a-b)$ $(p<0.05)$

TPC total phenolic content, ns no significance 
Table 7: Antioxidant capacity of Arbequina EVOO samples

\begin{tabular}{|l|c|c|}
\hline Antioxidant capacity & $(\mathrm{NS})$ & $($ IS $)$ \\
\hline ABTS $(\mu \mathrm{g}$ Trolox/g oil $)$ & $551.38 \pm 32.91^{\mathrm{a}}$ & $198.94 \pm 5.31^{\mathrm{b}}$ \\
\hline DPPH $(\mu \mathrm{g}$ Trolox/g oil $)$ & $536.44 \pm 17.13^{\mathrm{a}}$ & $56.69 \pm 7.78^{\mathrm{b}}$ \\
\hline ORAC $(\mu \mathrm{mol} / 100 \mathrm{~g}$ oil $)$ & $503.67 \pm 0.00^{\mathrm{a}}$ & $272.49 \pm 31.31^{\mathrm{b}}$ \\
\hline
\end{tabular}

Significant differences in the same row are shown by different lower case letters $(a-b)$ $(p<0.05)$

$N s=$ no significance

Table 8: Squalene, $\beta$-carotene and chlorophyll- a content of Arbequina EVOO

\begin{tabular}{|l|c|c|}
\hline $\begin{array}{l}\text { Other minor } \\
\text { components }\end{array}$ & $\begin{array}{l}(\mathrm{NS}) \\
(\mathrm{mg} / \mathrm{kg})\end{array}$ & $\begin{array}{l}(\mathrm{IS}) \\
(\mathrm{mg} / \mathrm{kg})\end{array}$ \\
\hline Squalene & $1526.36 \pm 0.98^{\mathrm{a}}$ & $3494.68 \pm 22.15^{\mathrm{b}}$ \\
\hline$\beta$-Carotene & $0.20 \pm 0.00^{\mathrm{ns}}$ & $0.19 \pm 0.02^{\mathrm{ns}}$ \\
\hline Chlorophyll-a & $0.52 \pm 0.00^{\mathrm{a}}$ & $0.64 \pm 0.00^{\mathrm{b}}$ \\
\hline
\end{tabular}

Significant differences in the same row are shown by different lower case letters $(a-b)$ $(p<0.05)$

$N s=$ no significance 










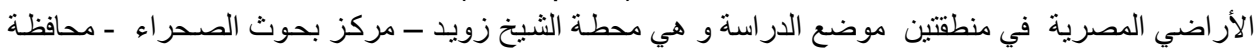

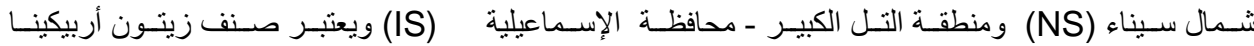































الكلمات المفتاحية: زيت الزيتون البكر الممتاز (إيفو) · أربيكينا متنو عة · الفينوليكس · توكوفيرول · سكو الين 